\title{
Acreditação Institucional e Certificação Profissional: seminário da Cinaem
}

Hêider A. Pinto ${ }^{1}$

Reinaldo Ayer de Oliveira ${ }^{2}$

No primeiro fim de semana de maio do ano 2000, a Cinaem (Comissão Interinstitucional Nacional de Avaliação do Ensino Médico) mais uma vez amplia $e$ avança: realiza, em São Paulo, um seminário internacional para debater Acreditação Institucional e Certificação Profissional e envolve, nessa discussão, mais de cincoenta escolas médicas, todos os conselhos regionais de medicina, mais de vinte sindicatos médicos, entidades representativas da área associativa da medicina, estudantes $e$ representantes das 11 entidades que compõem a Cinaem.

O seminário foi organizado como espaço de debate entre os conhecimentos (saberes) sobre a acreditação e certificação $e$ as posições dos participantes (práticas), temas tão pertinentes na evolução do projeto da Cinaem e já objetos de estudos e proposições em vários fóruns internacionais. Uma vez que a repercussão dessas discussões afetará os destinos da escola médica e da atividade profissional na América Latina, especialmente no Brasil, não
Os dez anos do movimento

geraram uma nova cultura

instituinte na educação médica

com vocabulário, valores,

saberes e entendimentos

inovadores e comprometidos

com a transformação;

produzindo qualificado

diagnóstico da educação

médica; e possibilitando a

construção coletiva das

diretrizes para a docência

médica, o sistema de

avaliação, a gestão da escola e

o processo de formação

necessárias para a produção

de uma escola médica de

qualidade no entendimento dos

atores que deram vida ao

processo.

há tempo a perder: entidades e escolas médicas devem, urgentemente, aprofundar

o debate.

Os temas propostos geraram, ao longo do

Seminário, polêmicas em várias direções, especialmente no que se referiu a mecanismos de classificação institucional $e$ regulamentação profissional. Trouxeram à tona discussões complexas e controvertidas que vão, de um recorte simplista que considera um sistema de acreditação organizado sobre uma lógica excludente, competitiva, lucrativa e orientada para responder ao mercado a concepções segundo uma ótica includente, eqüânime, cooperativa, solidária, formativa, democrática, que objetiva a construção de um aparelho formador que responda às necessidades do sistema de saúde e da população. Possibilitar um debate democrático e coletivo como o que foi visto durante o Seminário mostra maturidade e afirmação do movimento de transformação da educação médica orientado pela Cinaem.

Os desdobramentos deste Seminário prometem inaugurar uma unidade de políticas e objetivos entre as entidades que formam este corpo, respeitando as singularidades, atribuições e motivações de cada uma. Para um caminhar solidário e responsável é necessário que a discussão seja agendada nacionalmente, tomando-se o cuidado de não afastar um importante parceiro: o Estado.

\footnotetext{
${ }^{1}$ Coordenador Geral da Direção Executiva Nacional dos Estudantes de Medicina, DENEM/Movimento em Defesa da Vida; vicepresidente da Cinaem. <heiderap@hotmail.com>

${ }_{2}$ Conselheiro do Conselho Regional de Medicina do Estado de São Paulo (Cremesp); Professor da Faculdade de Medicina de Botucatu/ unesp.<ayer@fmb.unespbr>
} 
NOTAS BREVES

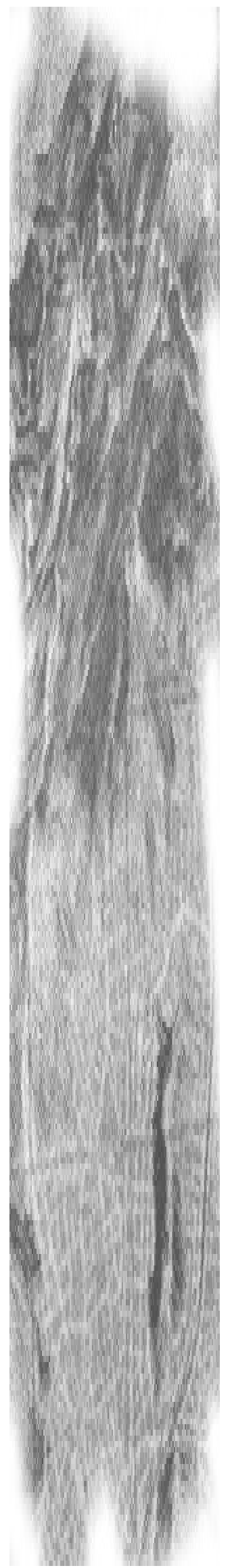

156 Interface - Comunic, Saúde, Educ 7 